\title{
Effect of Lithium Based Admixtures on Alkali Silica Reaction in Concrete and Flexural Behavior of Reinforced Concrete Rectangular Beams
}

\author{
S. Sathya ${ }^{1}$ and R. Manju ${ }^{2}$ \\ ${ }^{1}$ PG Student, ${ }^{2}$ Assistant Professor (SRG), \\ Department of Civil Engineering, Kumaraguru College of Technology, Tamil Nadu, India \\ E-Mail: sathya169454@gmail.com,manju.r.ce@kct.ac.in
}

\begin{abstract}
In recycling of lithium-ion batteries, lithium is a challenging element, which possesses great threat to the environment. The disposal of electronic waste is a major problem, which our country is currently facing, whereas, the lithium is one of the compound in electronic waste which challenges the recycling of lithium-ion batteries. If lithium is properly extracted, it can be used for structural engineering purpose. Lithium, if used in concrete, it controls the cracks due to alkali silica reaction (ASR), resulting in increased strength and durability of the concrete. Lithium based admixtures are effective in suppression of alkali silica reaction and delayed ettringite formation, if the dosage added in concrete is appropriate. The main objective of this paper is to assess the effectiveness of $\mathrm{LiNO}_{3}$ at various dosage levels in concrete. In this paper, the effect of $\mathrm{LiNO}_{3}$ on the mechanical properties of concrete, ASR gel formation and the flexural behavior of reinforced concrete rectangular beams are studied. The mechanical properties of concrete was investigated for six mix proportions comprising of control mix, lithium nitrate at $0.6 \mathrm{M}$, 0.65M, 0.7M, 0.75M, 0.8M. $\mathrm{LiNO}_{3}$ not only prevents the ASR gel formation, but also it has great influence on mechanical properties of concrete. The results indicate that the concrete with $0.75 \mathrm{M} \mathrm{LiNO}_{3}$ has higher strength values. SEM analysis has been performed for $0.75 \mathrm{M}$ and control mix to study the micro characteristics of concrete. The ASR gel formed in $0.75 \mathrm{M}$ has been suppressed as compared to that of concrete without lithium nitrate as an admixture. The durability studies are performed in concrete for water permeability, water absorption and rapid chloride penetration characteristics. The analytical study of flexural behavior of reinforced concrete rectangular beam is done using the software ANSYS 16.0.

Keywords: Alkali Aggregate Reaction, Cracks, Lithium admixtures, Optimum Dosage, Mechanical Properties, Durability Properties, Flexural Property
\end{abstract}

\section{INTRODUCTION}

Concrete is a composite material composed of cement, fine and coarse aggregate bonded together in the presence of water which hardens over time. Cracks in concrete are irregular and cannot be prevented. If causes were better understood, the elimination of cracks would be less difficult. A crack in concrete is mainly due to in adequate investigation of all the ingredients involved. Cracking can be the result of one or a combination of factors such as chemical reaction, drying, creep \& shrinkage, thermal cracking, moisture movement, elastic deformation, foundation movements and settlement of soil, manufacturing defects. The cracks due to chemical reaction are mainly due to alkali aggregate reaction.

Aggregates contain reactive silica, which reacts with alkali present in the cement. Certain types of reactive aggregates are responsible for alkali aggregate reaction. The reaction starts with the attack of reactive siliceous minerals in the aggregate by hydroxyl ions derived from alkalis in the cement, resulting in the unlimited swelling of alkali silicate gel, which leads to disruption of concrete, with the spreading of cracks and it may eventually leads to failure of concrete structures. There are three types of alkali aggregate reaction, in which, the alkali-silica reaction commonly known as "concrete cancer". It is the swelling of concrete due to the reaction between high alkaline cement paste and reactive silica in the aggregate in the presence of sufficient moisture.

This reaction causes expansion of aggregate by forming soluble viscous gel sodium silicate $\mathrm{Na}_{2} \mathrm{SiO}_{3} \cdot n \mathrm{H}_{2} \mathrm{O}$. On absorbing water, this gel swells and increases in its volume. It exerts pressure inside the siliceous aggregate, causes spalling of concrete and results in the reduction of strength. ASR leads to severe cracks, leads to severe structural problem, which finally leads to destruction of the structure. If lithium based admixture is used in concrete, it reacts with silica before the hydroxyl ions, forming lithium sulphate $\left(\mathrm{Li}_{2} \mathrm{SO}_{3}\right)$, which serves as a diffusion barrier and protective layer to prevent alkali silica reaction, which in turn leads to prevention of cracks. Investigations were done on the early age hydration of cement - fly ash blend with six different compositions of cement. The dosage of lithium added was $0-400 \%$. It was observed that higher dosages increased the autogeneous shrinkage after 40 days. Lithium Nitrate accelerated the early hydration. The $100 \%$ dosage means the 0.74 lithium to alkali molar ratio.

The reaction between the fly ash and Lithium Nitrate decreases the early heat and mitigates Alkali Silica Reaction [M.J.Millard et al., ${ }^{1} 2008$ ]. The addition of lithium nitrate decreased the dissolution rate and solubility of silica. In mortar, addition of lithium nitrate, decreases the calcium, sodium and potassium content and changes the reaction product from porous plate like configuration to a dense one without texture. The suppression of alkali silica gel is due to the lower potential of the reaction product to swell. The dissolution rate of silica slows down when lithium nitrate 
combines with caustic soda and reduces its solubility [Andreas Leemann et al., ${ }^{2} 2014$ ]. The alkali aggregate reaction can be restrained by lithium salts but its influence on initial setting time and strength is uncertain. The lithium sulphate accelerates the cement hydration and shortens the setting time and improves the early strength but it does not have any reverse effect on ultimate strength. The lithium sulphate decreases the initial and final setting time by 4$20 \%$, such that it accelerates the setting. Lithium sulphate increases the rate of early strength development. Lithium ion decreases the calcium ion stability and reduces the nucleation barrier of ettringite, such that growth of hydration products takes place. Sulphate ion accelerates the formation hydration products [Deng et al., ${ }^{3}$ 2014].

Investigation on themechanism of alkali silica reaction was made, especially molecular to micro scale levels is not clearly understood and it resulted in inability to assess its risk. This study states that aggregate reactivity depends on the size and distribution of minerals in addition to that of silica content. The presence of calcium is required for the ASR formation. Among the lithium based admixtures use in the study, the lithium nitrate efficiently controls ASR [Farshad Rajabipour et al, ${ }^{4} .2015$ ]Expansion of mortar bars with 6 dosage of lithium to alkali molar ratio 0.59, 0.74, $0.89,1.04,1.19 \& 1.33$ with six reactive type aggregates were studied. As a result, the amount of lithium salt needed to suppress ASR induced mortar expansion values depends on the extent of reactivity of aggregate mineralogy and the duration of the test.

Lithium nitrate found to be more effective for reactive type of aggregates [Mohammad S. Islam et al, ${ }^{5}$. 2016]. The influence of lithium on composition of alkali silica reaction gel was studied. The average of $\mathrm{CaO} / \mathrm{SiO}_{2}$ ratio decreases with the increase in amount of lithium Salts added. The optimum dosage level of $\mathrm{LiOH}$ and $\mathrm{LiNO}_{3}$ in reduction of ASR gel was $0.75 \mathrm{M}$ with the high alkali cement of $1.1 \%$ $\mathrm{NaO}_{\mathrm{e}}$. ASR gel becomes a homogeneous compound at high dosage levels of $\mathrm{CaO}\left[\right.$ Kawamura et al., ${ }^{6}$ 2003]. In the presence of lithium in concrete, there is a formation of two products, viz., crystalline lithium silicate and lithium bearing, which serves as a diffusion barrier and as a protective layer to prevent alkali silica reaction.The studies include, expansion testing and silica dissolution measurements, from which its proved that lithium reacts easily with the reactive type of aggregates than non-reactive type of aggregates [Feng et al.,7 2010].

Alkali silica reaction in concrete was examined using $\mathrm{LiF}$, LiCl, LiBr, LiOH, LiOH. $2 \mathrm{H}_{2} \mathrm{O}, \mathrm{LiHNO}_{3}, \mathrm{LiNO}_{3}, \mathrm{LiCO}_{3}$, $\mathrm{Li}_{2} \mathrm{SO}_{4}, \mathrm{Li}_{2} \mathrm{HPO}_{4}$ and these compounds are effective in suppressing ASR. $\mathrm{LiNO}_{3}$ shows better efficiency in mitigating alkali silica reaction. The lithium alkali molar ratio which efficiently inhibits alkali silica reaction lies between 0.67 and 1.2 for other lithium salts and for lithium nitrate, it lies between 0.72 and 0.93 [Feng et al., ${ }^{8}$ 2005]. The mechanism of aluminium containing metakaolin and $\mathrm{LiNO}_{3}$ against alkali silica reaction was investigated. The addition of metakaolin slows down the silica dissolution rate but there is no affect on final product, i.e. the aluminium ions only influences the kinetics of the reaction but not on the product. Metakaolin and $\mathrm{LiNO}_{3}$ has an ability to reduce the ASR expansion. $\mathrm{LiNO}_{3}$ can suppress the ASR by forming dense product i.e. the reactive minerals are protected by the formation of layer around the aggregates [Andreas Leemann et al., ${ }^{9}$ 2015].The effects of lithium additives - $\mathrm{LiOH}, \mathrm{LiCl}$, and $\mathrm{LiNO}_{3}$ on alkali silica reaction were examined at various dosages. The expansion was below the acceptable limit of $0.05 \%$ at 56 days.

The optimum dosage of $\mathrm{Li}_{2} \mathrm{O} / \mathrm{Na}_{2} \mathrm{O}_{\mathrm{e}}$ to control alkali silica reaction was approximately 0.6 for $\mathrm{LiOH}, 0.8 \& 0.9$ for $\mathrm{LiNO}_{3}$ and LiCl respectively, and the mechanism behind the alkali silica suppression due to addition lithium salts was not clear.Lithium salts either decrease the silica dissolution or the precipitation of silica rich products because, the dissolved silica concentration decreased with increase in dosage of lithium salts [Collins, C. L, et al., ${ }^{10}$ 2004].The mortars containing gravel as aggregate with $\mathrm{LiNO}_{3}$ has been tested. The lithium ion decreases the expansion of mortar than standard specifications and also there is reduction in micro cracks due to the lower swelling capacity of the gels. Alkali aggregate reaction causes internal corrosion which leads to damage of the structure.The optimum $\mathrm{Li} / \mathrm{Na}_{2} \mathrm{O}_{\mathrm{e}}$ was found to be 0.74 [Zapała- Sławeta et al., ${ }^{11} 2016$ ].

The physical and chemical changes on account alkali silica reaction were studied in the presence of lithium ions. The pore solution of the mortar with different dosage $(0 \%, 35 \%$, $100 \%)$ was studied. Lithium ion prevents the dissolution of silica and a physical barrier was formed on the surface of reactive silica, which is facilitated by lithium ions and thus prevents ASR gel formation [Kim Taehwan et al., ${ }^{12} 2016$ ]. Tests are done on low and high alkali cement paste with and without the addition of $\mathrm{LiNO}^{3}$ and lithium bearing glass. The $\mathrm{Li} / \mathrm{Na}_{2} \mathrm{O}_{\mathrm{e}}$ molar ratio was kept constant 0.74 . The pore solution of three types of specimen were tested which has been subjected to $23,38 \& 60^{\circ} \mathrm{C}$ in sealed container at 3,7 , 28\& 91 days. It has been stated that $\mathrm{LiNO}_{3}$ decreases $\mathrm{pH}$ by 0.1 and lithium glass increases the $\mathrm{pH}$ by 0.2 . In mixtures which were made with lithium glass, lithium ion was not rapidly released by Li-glass under normal conditions, temperature and $\mathrm{pH}$. The temperature between $23 \& 60^{\circ} \mathrm{C}$ has no significant influence on the density of the pore solution [Bérubé et al., ${ }^{12}$ 2016].

\section{MATERIALS USED}

\section{A. Ordinary Portland Cement}

Ordinary Portland Cement confirming to 43 grade was used. The cement used was having the standard consistency of $34 \%$ with initial setting time of 75 minutes and the final setting time of 600 minutes. The fineness of the cement was found to be 8\% (as per IS: 4031 part 1 - 1996) and with the specific gravity of 3.15 . 


\section{B. Fine Aggregates}

Fine aggregates generally consist of natural sand or crushed stone passing through $4.75 \mathrm{~mm}$ sieve. In this project, MSand is used. The fine aggregate has direct impact on workability and uniformity of the mixture. The fine aggregates also assist the polymer to hold the coarse aggregates in suspension. Thus, the segregation of paste and coarse aggregates has been prevented due to former action which promotes plasticity.Properties of Fine Aggregate are described in Table I.

TABLE I PROPERTIES FINE AGGREGATE

\begin{tabular}{|c|l|c|c|}
\hline $\begin{array}{c}\text { S. } \\
\text { No }\end{array}$ & \multicolumn{1}{|c|}{$\begin{array}{c}\text { Property of Fine } \\
\text { Aggregate }\end{array}$} & $\begin{array}{c}\text { River } \\
\text { sand }\end{array}$ & M - sand \\
\hline 1. & Specific gravity & 2.4 & 2.67 \\
\hline 2. & Grading of Aggregates & $\begin{array}{c}\text { Confirming to } \\
\text { Zone II }\end{array}$ & $\begin{array}{c}\text { Confirming to } \\
\text { Zone II }\end{array}$ \\
\hline 3. & Water Absorption & $1.3 \%$ & $1 \%$ \\
\hline 4. & Moisture Content & NIL & NIL \\
\hline
\end{tabular}

\section{Coarse Aggregates}

Coarse aggregates are particles greater than $4.75 \mathrm{~mm}$, but generally range between $9.5 \mathrm{~mm}$ to $37.5 \mathrm{~mm}$ in diameter. The crushed blue aggregates conforming to $20 \mathrm{~mm}$ and $12 \mathrm{~mm}$ were used. It provides strength, toughness and hardness to concrete. The presence of coarse aggregates imparts chemical resistance, free and thaw resistance and abrasive resistance to concrete. It also imparts flexural and impact strength.Properties of Fine Aggregate are described in Table II.

TABLE II PROPERTIES OF COARSE AGGREGATE

\begin{tabular}{|c|c|c|}
\hline S. No & Property of Coarse Aggregate & Values \\
\hline 1. & Specific Gravity & 2.76 \\
\hline 2. & Water Absorption & $0.4 \%$ \\
\hline 3. & Moisture content & NIL \\
\hline
\end{tabular}

\section{Lithium Nitrate}

Lithium nitrate is an inorganic compound. Its physical state is Solid. The molecular mass is $68.946 \mathrm{~g} / \mathrm{mol}$. It is a colorless powder. The melting point of lithium nitrate is 264 ${ }^{\circ} \mathrm{C}$ and boiling point is $600{ }^{\circ} \mathrm{C}$. Its relative density is 2.4 . The density of lithium nitrate is $2380 \mathrm{~kg} / \mathrm{m}^{3}$. It is soluble in water, ethanol and in other organic solvents.

\section{E. Mix Proportion}

The mix proportions were designed as per IS: 10262 - 2009. The mix proportion of 1:1.79: 3: 0.5 (cement: fine aggregates: coarse aggregates: water) by weight of cement was used throughout Table III describes the mix description for various mixes.
TABLE III MIX DESCRIPTION

\begin{tabular}{|c|c|c|c|c|}
\hline $\begin{array}{c}\text { Mix } \\
\text { ID }\end{array}$ & $\begin{array}{c}\text { W/C } \\
\text { ratio }\end{array}$ & $\begin{array}{c}\text { Volume of } \\
\text { Concrete } \\
\mathbf{( m}^{\mathbf{3}} \mathbf{)}\end{array}$ & $\begin{array}{c}\text { Lithium } \\
\text { nitrate } \\
\text { (Molarity) }\end{array}$ & $\begin{array}{c}\text { Lithium } \\
\text { nitrate } \\
\text { (grams) }\end{array}$ \\
\hline $\mathrm{CM}$ & 0.5 & 0.078 & 0 & 0 \\
\hline $0.80 \mathrm{M}$ & 0.5 & 0.078 & 0.8 & 106 \\
\hline $0.75 \mathrm{M}$ & 0.5 & 0.078 & 0.75 & 100 \\
\hline $0.70 \mathrm{M}$ & 0.5 & 0.078 & 0.7 & 93 \\
\hline $0.65 \mathrm{M}$ & 0.5 & 0.078 & 0.65 & 86 \\
\hline $0.60 \mathrm{M}$ & 0.5 & 0.078 & 0.6 & 80 \\
\hline
\end{tabular}

\section{EXPERIMENTAL PROGRAMME}

\section{A. Aggregate Reactivity Test Accelerated Mortar Bar Expansion Test (As per ASTM C 1260 standards)}

The fine aggregate was tested for ASR using ASTM standards for potential reactivity of the aggregates. The mortar bars of $25 \mathrm{~mm}$ x $25 \mathrm{~mm}$ x $285 \mathrm{~mm}$ were made with the w/c of 0.47.Cement Mortar ratio is 1: 2.25. After demoulding, it should be placed in a water bath at $80^{\circ} \mathrm{C}$ for next 24 hours. The initial length should be measured after removal from the water bath and then it should be stored in highly alkaline solution of $1 \mathrm{~N} \mathrm{NaOH}$ at $80^{\circ} \mathrm{C}$. The readings should be taken for a 14 days period with at least 3 subsequent readings.If the length expansion is $<0.1 \%$ means that the aggregate is non - reactive, 0.1 to $0.2 \%$ means potentially reactive, $>0.2 \%$ meansreactive aggregates.

\section{B. Tests for Hardened Properties of Concrete}

Concrete is strong in compression. Higher the compressive strength better is the durability and bond strength. Resistance to abrasion and volume stability improves with the compressive strength which is very important quality of concrete. For compression strength test, the concrete samples shall be taken and used for casting cubes are of $150 \mathrm{~mm} \times 150 \mathrm{~mm} \times 150 \mathrm{~mm}$. Tensile strength is one of the basic and important properties of the concrete. The concrete is not usually expected to resist the direct tension because of its low tensile strength and brittle nature. However the determination of tensile strength of concrete is necessary to determine the load at which the concrete members may crack. The cracking is a form of tensile failure. Because of the difficulties associated with the direct tension test, a number of indirect methods have been developed to determine the tensile strength. Hence, splitting tensile strength test has been done as per IS: 5816 - 1970. Flexure Strength Test is used to determine the flexural capacity of the concrete as per IS: 516-1959with beam mould of size $100 \times 100 \times 500 \mathrm{~mm}$. 


\section{SEM Analysis}

The samples were carbon coated and analyzed using Scanning Electron Microscope (SEM) in the back scattered electron mode with an accelerating voltage of $10 \mathrm{kV}$. For each sample, the back scattered was set to the same parameter. Through SEM analysis, the surface morphology and particle size of the powdered specimen can be determined. Images for different samples were taken at various magnifications like X500, X1000, X5000, X10000 to identify the texture and crack. In, this project, SEM analysis is to be done for the reference concrete sample and then the concrete which contains optimum lithium admixture. SEM analysis is used to study the suppression of alkali aggregate reaction and the ettringite formation.

\section{Tests for Durability Properties of Concrete}

Durability of concrete is defined as the ability of concrete to resist weathering action, chemical attack, and abrasion while maintaining its desired engineering properties.To assess the durability properties of concrete, Rapid chloride Penetration Test, Water Absorption, Water Permeability Test and Carbonation Tests has been done.

\section{RESULTS AND DISCUSSIONS}

\section{A. Alkali Aggregate Reactivity Test}

In aggregate reactivity test, River sand is inactive in highly alkaline medium, whereas $\mathrm{M}$ Sand has found to be reactive with the average length expansion of about $0.45 \%$. Table IV indicates the accelerated mortar bar expansion test for river sand and M Sand.

TABLE IV ACCELERATED MORTAR BAR EXPANSION TEST

\begin{tabular}{|c|c|c|c|c|c|c|}
\hline Mate & & 氖氞 & 㺃胥 & 泀 & 预 & ○。 总 \\
\hline & $\begin{array}{l}S \\
1\end{array}$ & 295 & 295 & 295 & 295 & 0 \\
\hline $\begin{array}{l}\text { CM } \\
\text { (River }\end{array}$ & $\begin{array}{l}S \\
2\end{array}$ & 295 & 295 & 295 & 295 & 0 \\
\hline & $\begin{array}{l}S \\
3\end{array}$ & 295 & 295 & 295 & 295 & 0 \\
\hline & S1 & 295 & 296 & 296 & 297 & 0.6 \\
\hline $\begin{array}{l}\text { CM } \\
\text { (M }\end{array}$ & $\begin{array}{l}S \\
2\end{array}$ & 295 & 296 & 296 & 296 & 0.3 \\
\hline Sand) & $\begin{array}{l}S \\
3\end{array}$ & 295 & 295 & 296 & 296 & 0.3 \\
\hline
\end{tabular}

\section{B. Tests Results for Mechanical Properties of Concrete}

\section{Compressive Strength}

The compressive strength test results are given in table 4.1. The compressive strength tests were done at $7^{\text {th }}, 28^{\text {th }} \& 90^{\text {th }}$ day. The maximum compressive strength at $28^{\text {th }} \& 90^{\text {th }}$ day of $30.93 \mathrm{MPa}$ and $34.95 \mathrm{MPa}$ was achieved for the mix which contains $0.75 \mathrm{M}$ of lithium nitrate. Whereas, the compressive strength of 28.98MPa, 27.78MPa, 27.21MPa, $27.16 \mathrm{MPa}$ were achieved for concrete containing $0.80 \mathrm{M}$, $0.70 \mathrm{M}, 0.65 \mathrm{M}, 0.60 \mathrm{M}$ of lithium nitrate at $28^{\text {th }}$ day respectively.

For, the concrete containing $0.75 \mathrm{M}$ of lithium nitrate, the Percentage increase in strength at $28^{\text {th }}$ on comparison with control mix was $14.30 \%$. Table 5 gives the detailed description about the compressive strength. Fig 1 compares the $7^{\text {th }}, 28^{\text {th }} \& 90^{\text {th }}$ day compressive strength.

TABLE V COMPRESSIVE STRENGTH TEST RESULTS

\begin{tabular}{|c|c|c|c|c|c|}
\hline 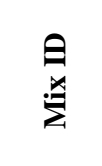 & 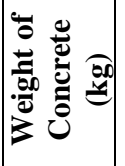 & 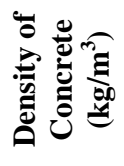 & 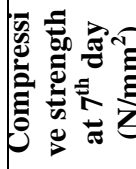 & 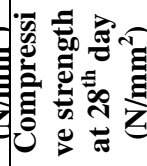 & 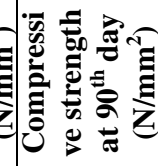 \\
\hline $\mathrm{CM}$ & 8.40 & 2488.89 & 15.18 & 27.06 & 30.77 \\
\hline $0.80 \mathrm{M}$ & 8.55 & 2533.33 & 17.26 & 28.98 & 34.22 \\
\hline $0.75 \mathrm{M}$ & 8.68 & 2571.85 & 18.49 & 30.93 & 34.95 \\
\hline $0.70 \mathrm{M}$ & 8.50 & 2518.52 & 16.48 & 27.78 & 33.78 \\
\hline $0.65 \mathrm{M}$ & 8.43 & 2497.78 & 16.08 & 27.21 & 32.36 \\
\hline $0.60 \mathrm{M}$ & 8.42 & 2494.80 & 15.49 & 27.16 & 31.66 \\
\hline
\end{tabular}

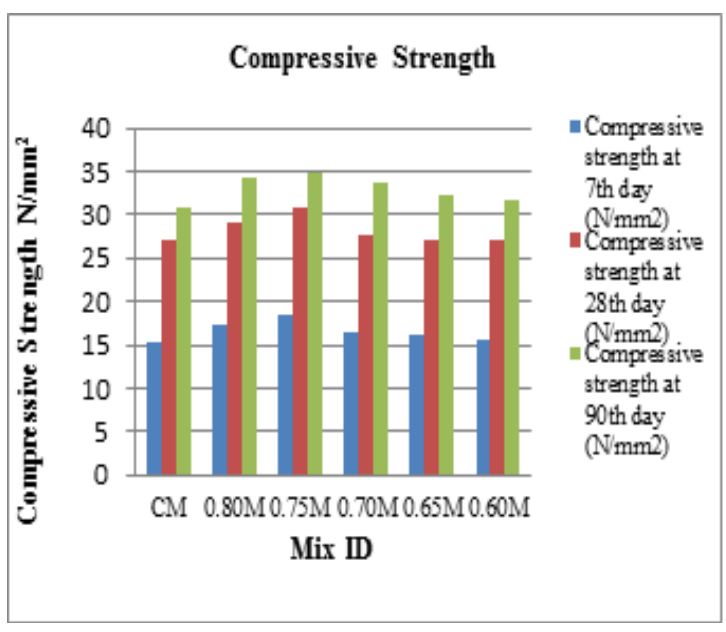

Fig. 1 Compressive Strength Test Results for various mixes

\section{B. 2 Split Tensile Strength}

The split tensile strength test is the indirect method to assess the tensile capacity of the concrete. The tensile strength of concrete for $0.75 \mathrm{M}$ was $33.87 \%$ higher than that of reference concrete i.e, tensile strength of $1.66 \mathrm{MPa}$ was achieved. The detailed description of tensile strength for various mixes was shown in Table 6 . Fig 2 compares the $7^{\text {th }}$ and $28^{\text {th }}$ day compressive strength. 
TABLE VI SPLIT TENSILE STRENGTH TEST RESULTS

\begin{tabular}{|c|c|c|c|}
\hline $\begin{array}{c}\text { Mix } \\
\text { ID }\end{array}$ & $\begin{array}{l}\text { Split Tensile } \\
\text { Strength at } 7^{\text {th }} \\
\text { day }\left(\mathbf{N} / \mathbf{m m}^{2}\right)\end{array}$ & $\begin{array}{l}\text { Split tensile } \\
\text { strength at } 28^{\text {th }} \\
\text { day }\left(\mathrm{N} / \mathbf{m m}^{2}\right)\end{array}$ & $\begin{array}{c}\text { Percentage } \\
\text { increase in } \\
\text { strength } \\
(\%)\end{array}$ \\
\hline $\mathrm{CM}$ & 0.9 & 1.24 & - \\
\hline $0.80 \mathrm{M}$ & 1.01 & 1.52 & 22.58 \\
\hline $0.75 \mathrm{M}$ & 1.01 & 1.66 & 33.87 \\
\hline $0.70 \mathrm{M}$ & 0.91 & 1.48 & 19.35 \\
\hline $0.65 \mathrm{M}$ & 0.93 & 1.35 & 8.87 \\
\hline $0.60 \mathrm{M}$ & 0.94 & 1.29 & 4.03 \\
\hline
\end{tabular}

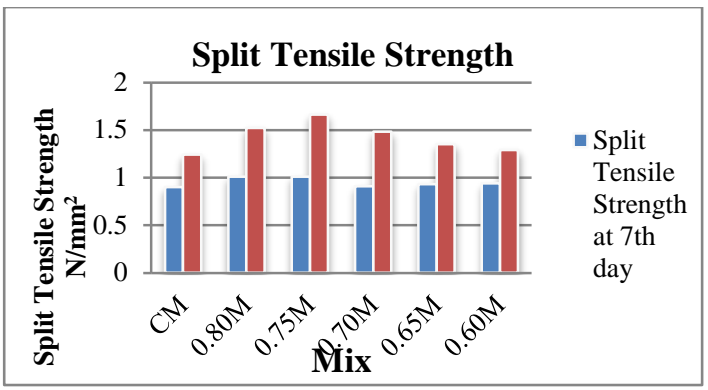

Fig. 2 Split Tensile Strength Results for various mixes B.3 Flexural Strength

The flexural strength evaluations of different concrete mixes after 28 days of curing subjected to two point loading. The flexural strength of the reference concrete is $3.85 \mathrm{MPa}$ which satisfies the flexural strength as per IS: 456 - 2000 (flexural strength $\left.=0.7 \checkmark \mathrm{f}_{\mathrm{ck}}\right)$. The flexural strength for $0.75 \mathrm{M}$ showed higher flexural strength than other mixes. Flexural strength test results were shown in Table VII.

TABLE VII FLEXURAL STRENGTH TEST RESULTS

\begin{tabular}{|c|c|c|}
\hline Mix ID & $\begin{array}{c}\text { Flexural Strength at } \\
28 \text { days N/mm }\end{array}$ & $\begin{array}{c}\text { Percentage increase in } \\
\text { strength }(\%)\end{array}$ \\
\hline $\mathrm{CM}$ & 3.85 & - \\
\hline $0.80 \mathrm{M}$ & 4.37 & 13.50 \\
\hline $0.75 \mathrm{M}$ & 4.63 & 20.26 \\
\hline $0.70 \mathrm{M}$ & 4.22 & 9.61 \\
\hline $0.65 \mathrm{M}$ & 3.88 & 0.79 \\
\hline $0.60 \mathrm{M}$ & 3.87 & 0.52 \\
\hline
\end{tabular}

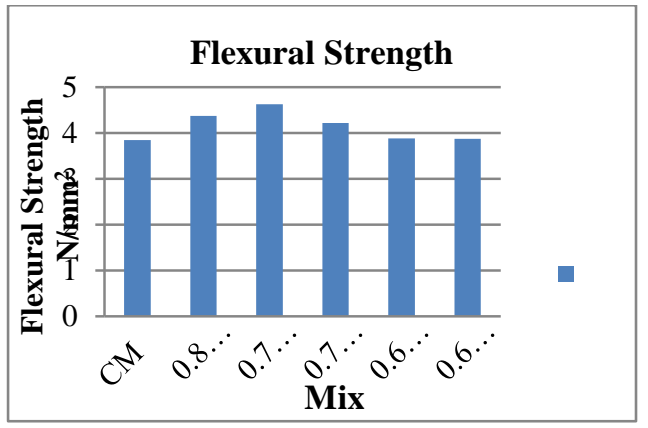

Fig. 3 Flexural Strength Results for various mixes

\section{SEM Analysis}

The samples were carbon coated and analyzed using Scanning Electron Microscope (SEM) in the back scattered electron mode with an accelerating voltage of $10 \mathrm{kV}$. The back scattered was set to the same parameter for each sample. Through SEM analysis, the surface morphology and particle size of the powdered specimen can be determined. Images for different samples were taken at various magnifications like X500, X1000, X5000, X10000 to identify the texture and crack. Image with magnification of X500 and X5000 is to be used for prediction of result.

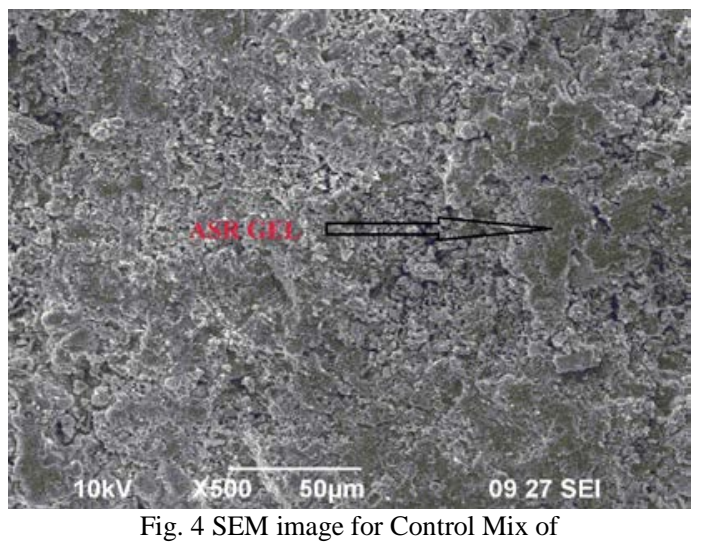
magnification X500

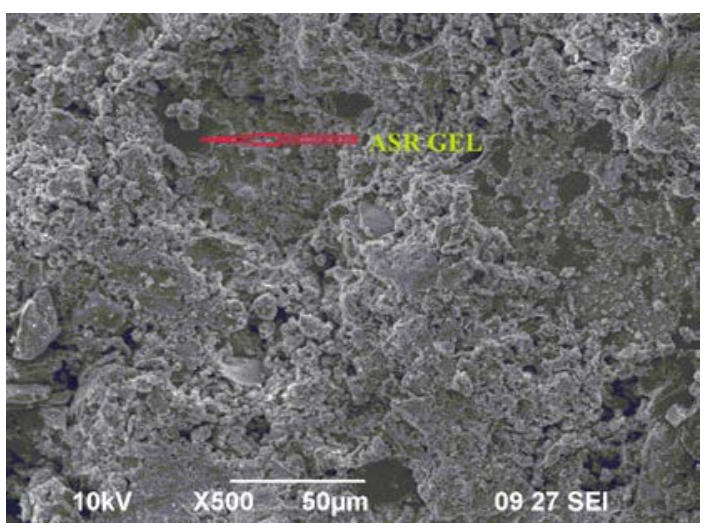

Fig. 5 SEM image for $0.75 \mathrm{M}$ of magnification X500

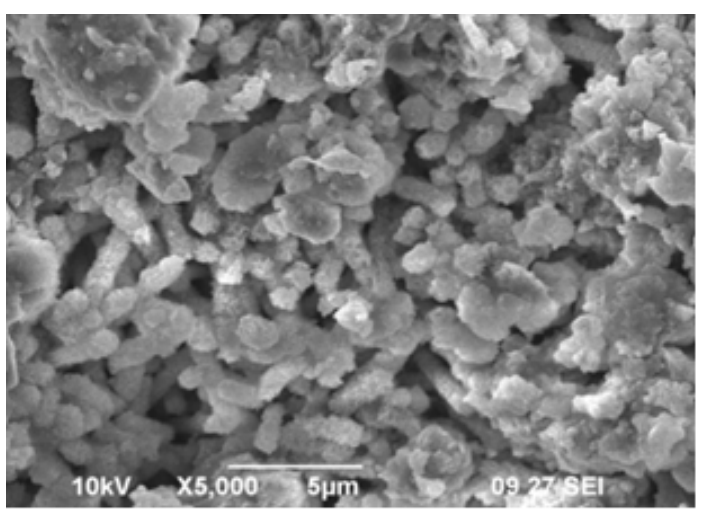

Fig. 6 SEM image for Control Mixof magnification X5000 


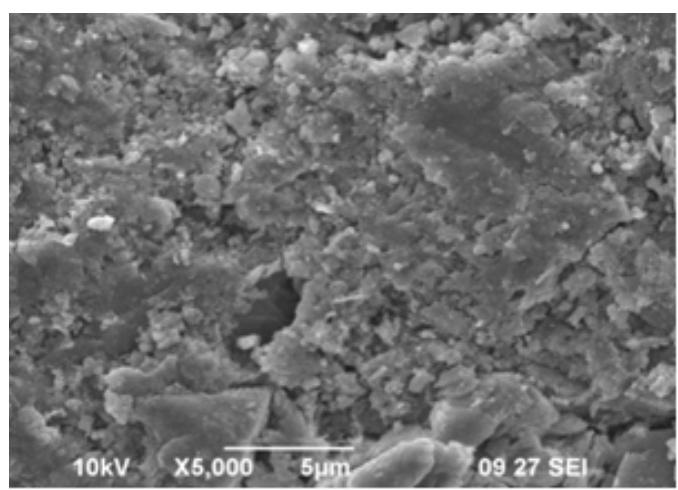

Fig. 7 SEM image for 0.75M of magnification X5000

From the above images, the alkali aggregate reaction has been taken place in reference concrete (control mix) which leads to more voids and permeable since and the formation of alkali silica gel is high. Whereas in concrete with lithium nitrate as an admixture, the quantity of alkali silica gel is minimum and the concrete has minimum voids and porosity. ASR in $0.75 \mathrm{M}$ has been suppressed and the crack formation has been minimized as compared to that of concrete without lithium nitrate as an admixture there is a delayed ettringite formation in lithium nitrate additive concrete.

\section{Durabilty Properties}

Durability of concrete is defined as the ability of concrete to resist weathering action, chemical attack, and abrasion while maintaining its desired engineering properties.

\section{Water Permeability Test}

As per IS 3085: 1965, Water absorption test is done on the concrete specimens of size $150 \mathrm{~mm} \mathrm{X} \mathrm{150mm} \mathrm{X} \mathrm{150mm.}$ The results indicate that the penetration of water has been significantly reduced in the mixes containing $\mathrm{LiNO}_{3}$, which in turn is supposed to increase the durability properties.

\section{TABLE VIII WATER PERMEABILITY TEST RESULTS}

\begin{tabular}{|c|c|}
\hline Mix ID & Depth of Penetration (mm) \\
\hline CM & 32 \\
\hline $0.80 \mathrm{M}$ & 25 \\
\hline $0.75 \mathrm{M}$ & 20 \\
\hline $0.70 \mathrm{M}$ & 28 \\
\hline $0.65 \mathrm{M}$ & 29 \\
\hline $0.60 \mathrm{M}$ & 30 \\
\hline
\end{tabular}

\section{Water Absorption Test}

Water absorption test is done on the concrete specimens of size $150 \mathrm{~mm} X 150 \mathrm{~mm}$ X 150mm. The incorporation of $\mathrm{LiNO}_{3}$ has decreased the water absorption in concrete specimen which in turn is supposed to increase the durability properties.
TABLE IX WATER ABSORPTION TEST RESULTS

\begin{tabular}{|c|c|c|c|c|}
\hline \multirow{2}{*}{ Mix ID } & \multicolumn{2}{|c|}{ Weight of Specimen (kg) } & \multirow{2}{*}{$\begin{array}{c}\text { Absorption } \\
\%\end{array}$} & \multirow{2}{*}{$\begin{array}{c}\text { Average } \\
(\%)\end{array}$} \\
\hline & Oven Dried & Saturated & & \\
\hline \multirow{2}{*}{$\mathrm{CM}$} & 8.744 & 8.841 & 1.11 & \multirow{2}{*}{1.025} \\
\hline & 8.812 & 8.896 & 0.95 & \\
\hline \multirow{2}{*}{$0.80 \mathrm{M}$} & 8.996 & 9.066 & 0.78 & \multirow{2}{*}{0.785} \\
\hline & 9.140 & 9.212 & 0.79 & \\
\hline \multirow{2}{*}{$0.75 \mathrm{M}$} & 8.605 & 8.660 & 0.64 & \multirow{2}{*}{0.75} \\
\hline & 8.999 & 9.076 & 0.86 & \\
\hline \multirow{2}{*}{$0.70 \mathrm{M}$} & 8.886 & 8.973 & 0.98 & \multirow{2}{*}{0.865} \\
\hline & 8.834 & 8.900 & 0.75 & \\
\hline \multirow{2}{*}{$0.65 \mathrm{M}$} & 8.912 & 9.004 & 1.03 & \multirow{2}{*}{0.925} \\
\hline & 8.830 & 8.902 & 0.82 & \\
\hline \multirow{2}{*}{$0.60 \mathrm{M}$} & 8.529 & 8.61 & 0.95 & \multirow{2}{*}{0.945} \\
\hline & 8.619 & 8.7 & 0.94 & \\
\hline
\end{tabular}

\section{Rapid Chloride Penetration Test}

Rapid chloride penetration test has been done as per AASHTO T277. The chloride permeability is very low for the concrete containing Lithium Nitrate as the admixture. Hence, the chance of corrosion is low.

\section{Carbonation Test}

$\mathrm{Ca}(\mathrm{OH})_{2}$ formed due to hydration of cement ensures $\mathrm{pH}$ value of concrete mass to lie up to 13.5 . Concentration of $\mathrm{CO}_{2}$ in air is between $0.03-0.3 \%$ by volume. Carbon dioxide present in the atmosphere reacts in the presence of water with hydrated cement. Calcium hydroxide gets converted to calcium carbonate and some other cement compounds gets decomposed and hence complete decomposition of calcium compound takes place. If freshly broken surface of concrete is exposed to a solution of phenolphthalein diluted in alcohol, unaffected area turns pink \& carbonated area remains uncolored. Pink color appears even up to $\mathrm{pH}$ value of about 9.5.Carbonation has not occurred in this investigation about lithium admixture concrete. Hence, the chances of corrosion are very less.

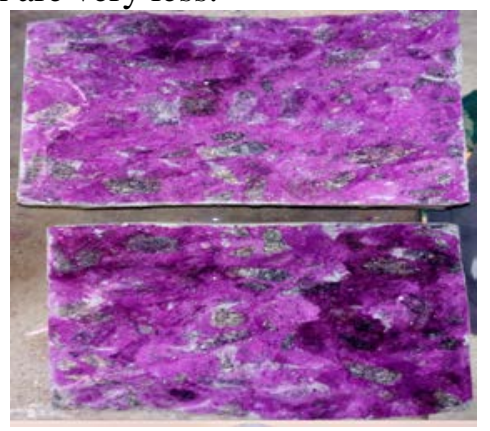

Fig. 8 Carbonation Test for 0.75M Concrete 


\section{ANALYTICAL PROGRAMME}

\section{A. Flexural Behavior of Rectangular Reinforced Concrete Beams Using ANSYS 16.0 Software}

The aim of this study was to understand the flexural behavior of reinforced concrete rectangular beams under two point loading condition. The model utilized to compute the flexural strength of reinforced concrete beams. The flexural behavior was studied analytically for two beams, control mix and the for the optimum mix dosage of lithium nitrate i.e. $0.75 \mathrm{M}$ mix. The parameters such as modulus of elasticity of concrete, strength, poison's ratio and stressstrain behavior has been given as input and the beam is modeled. The beam is modeled. The beam is meshed and the stress intensity pattern and total deformation of the beam were studied as shown in Fig. 9 \& 10. Fig.11 Shows the load deflection behavior of the beams.

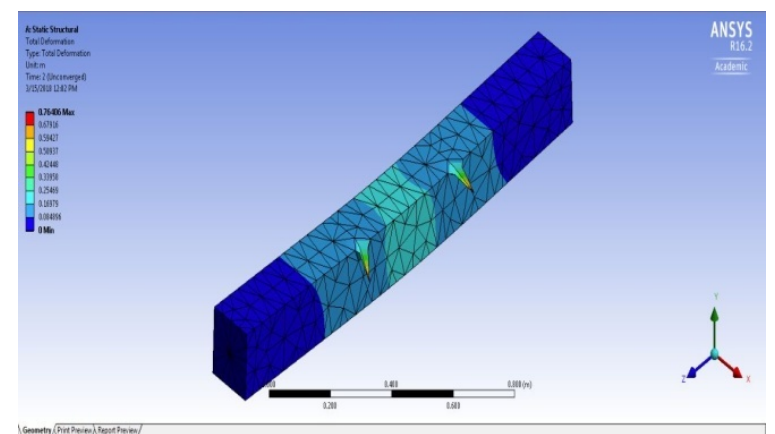

Fig. 9 Total Deformation Pattern of the 0.75M beam

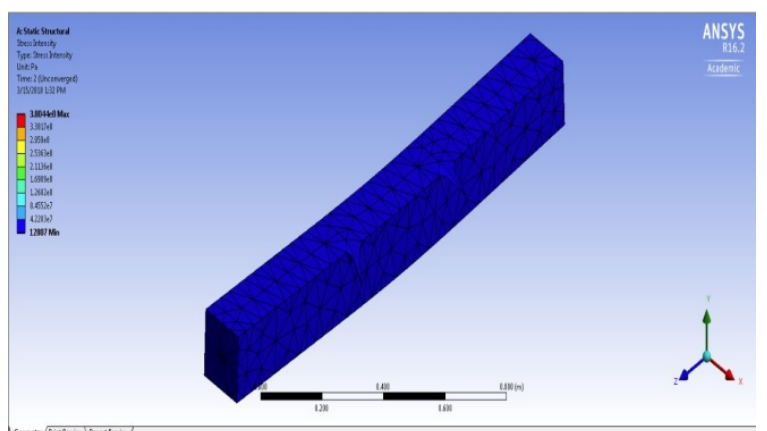

Fig. 10 Stress Intensity Pattern of the $0.75 \mathrm{M}$ beam

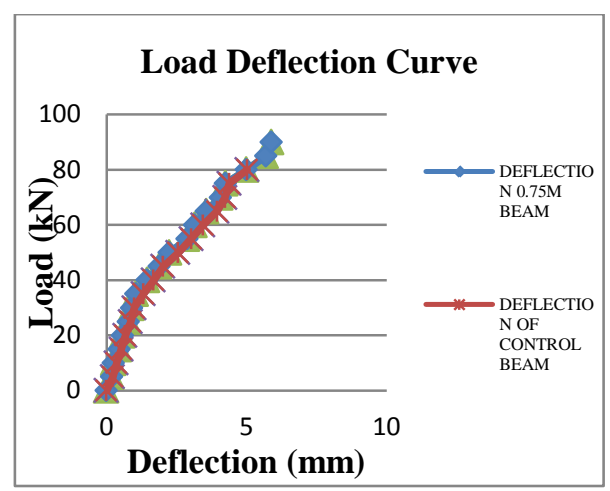

Fig. 11 Load Deflection Plot

\section{CONCLUSION}

From the above results and discussions, the following conclusions were made,

River sand is inactive in highly alkaline medium, whereas $\mathrm{M}$ Sand has found to be reactive with the average length expansion of about $0.45 \%$. The maximum compressive strength of $30.93 \mathrm{MPa}$ was achieved for the mix which contains $0.75 \mathrm{M}$ of lithium nitrate which is found to be $14.30 \%$ higher than reference concrete. The tensile strength of concrete for $0.75 \mathrm{M}$ was $33.87 \%$ higher than that of reference concrete i.e., tensile strength of $1.66 \mathrm{MPa}$ was achieved. The maximum flexural strength of 4.63MPa was achieved for the mix which contains $0.75 \mathrm{M}$ of lithium nitrate which is found to be $20.26 \%$ higher than reference concrete. Hence, the optimum dosage of $\mathrm{Li} / \mathrm{Na}_{2} \mathrm{O}_{e}$ was 0.75 for alkali suppression reaction.

From SEM image, it is clearly indicated that the ettringite formation in $0.75 \mathrm{M}$ mix is minimum. But in reference mix indicates the ettringite formation in huge amount. Hence, there is a delayed ettringite formation in lithium nitrate additive concrete. ASR in $0.75 \mathrm{M}$ has been suppressed and the crack formation has been minimized as compared to that of concrete without lithium nitrate as an admixture and has minimum voids and less permeable.

The incorporation of lithium nitrate has decreased the water absorption and water permeability of concrete. The occurrence of carbonation founds to be very less.

The flexural capacity of $0.75 \mathrm{M}$ beams is $12.5 \%$ higher than concrete without Lithium nitrate (reference concrete). Lithium compound is not economical, but its availability in e-waste is abundant, if extracted can be used for structural engineering purpose.

\section{REFERENCES}

[1] R. Manju and S. Sathya, "Effect of lithium based admixture on alkali aggregate reaction in concrete: A state of art Report", International Journal of Civil Engineering and Technology (IJCIET), Vol. 8, No. 9, pp. 299-304, September 2017.

[2] M. J. Millard and K. E. Kurtis, "Effects of Lithium Nitrate admixture on early-age cement hydration", Cement and Concrete Research, Vol. 38, No. 4, pp. - 500-510, 2008.

[3] Bashar Taha and Ghassan Nounu, "Using lithium nitrate and pozzolanic glass powder in concrete as ASR suppressors”, Cement and Concrete Composites, Vol. 30, No. 6, pp. 497-505, 2008.

[4] Leemann, Andreas, Lörtscher Luzia Bernard, Laetitia Le Saout, Gwenn Lothenbach, Barbara Espinosa Marzal and M. Rosa "Mitigation of ASR by the use of LiNO3 - Characterization of the reaction products", Cement and Concrete Research, Vol. 59, pp. 7386, 2014.

[5] Deng, Yuhai Zhang, Changqing Wei and Xiaosheng, "Influence of lithium sulfate addition on the properties of Portland cement paste", Construction and Building Materials, Vol. 50, pp. 457 - 462, 2014.

[6] Craig W. Hargis, Maria C. G. Juenger, and Paulo J. M. Monteiro, "Aggregate passivation: Lithium hydroxide aggregate treatment to suppress alkali-silica reaction”, ACI Materials Journal, Vol. 110 $567-575$, No. 5.

[7] Farshad Rajabipour, Eric Giannini, Cyrille Dunant, Jason H. Ideker and Michael D.A. Thomas, "Alkali - silica reaction: Current 
understanding of the reaction mechanisms and the knowledge gaps", Cement and Concrete Research, Vol. 76, pp. 130 - 146.

[8] Mohammad S. Islam, Nader Ghafoori, "Experimental study and empirical modeling of lithium nitrate for alkali-silica reactivity", Construction and Building Materials, Vol. 121, pp. 717 - 726, 2016.

[9] Lyndon D. Mitchell, "The effects of lithium hydroxide solution on alkali silica reaction gels created with opal”, Cement and Concrete Research, Vol. 34, No. 4, pp 641- 649, 2004.

[10] X. Feng, M. D A Thomas, T. W. Bremner, K. J. Folliard and B. Fournier, "Summary of research on the effect of LiNO3 on alkalisilica reaction in new concrete", Cement and Concrete Research, Vol. 40, No. 4, pp. 636-642, 2010.

[11] X. Feng, M. D. A. Thomas, T. W. Bremner, B. J Balcom and B. Fournier, "Studies on lithium salts to mitigate ASR-induced expansion in new concrete: A critical review", Cement and Concrete Research, Vol. 35, No. 9, pp. 1789 - 1796, 2005.

[12] C. L Collins, J. H. Ideker, G. S. Willis and K. E. Kurtis, "Examination of the effects of $\mathrm{LiOH}, \mathrm{LiCl}$, and $\mathrm{LiNO}_{3}$ on alkalisilica reaction", Cement and Concrete Research, Vol. 34, 2004, No. 8, pp. $1403-1415$

[13] Kawamura, Mitsunori and Fuwa Hirohito, "Effects of lithium salts on ASR gel composition and expansion of mortars", Cement and Concrete Research, Vol. 33, No. 6, pp. 913-919, 2003.
[14] Leemann Andreas, Bernard Laetitia, Alahrache Salaheddine and Winnefeld Frank, "ASR prevention - Effect of aluminum and lithium ions on the reaction products", Cement and Concrete Research, Vol. 76, pp. 192 - 201, 2015.

[15] J. Zapała-Sławeta and Z,Owsiak, "The role of lithium compounds in mitigating alkali-gravel aggregate reaction", Construction and Building Materials, Vol. 115, pp. 299-303, 2016

[16] Kim Taehwan and Olek Jan, "The effects of lithium ions on chemical sequence of alkali-silica reaction”, Cement and Concrete Research, Vol. 79, pp. 159-168, 2016.

[17] M. A Bérubé, C. Tremblay, B Fournier, M. D Thomas and D. B. Stokes, "Influence of lithium-based products proposed for counteracting ASR on the chemistry of pore solution and cement hydrates”, Cement and Concrete Research, Vol.79, pp. 159-168, 2016.

[18] IS: 10262 - 2009 Bureau of Indian Standards -Concrete Mix Proportioning - Guidelines

[19] IS: 456 - 2000Bureau of Indian Standards - Plain and Reinforced Concrete. 